\title{
PARADOXES OF THE MODERN ECONOMIC SCIENCE
}

K.K. Kumekhov ${ }^{1}$

N.G. Danilochkina ${ }^{2}$

V.I. Flegantov ${ }^{3}$

N.V. Cherner ${ }^{4}$

Abstract: The crisis of the economic science may be explained largely by several paradoxes making logical premises uncertain. Based upon the "methodological pluralism", they do not explain many fundamental matters making classification and accumulation of knowledge impossible. Our study aims to reveal (analysing modern economic theories by modelling) the main reasons of this state of the economic science, explain them scientifically and suggest the ways to eliminate them. By monographic studies, comparison and modelling, we have formulated the content of the scientific approach, its elements and their hierarchy. We have revealed the ways to implement scientific research and substantiated the need for economic modelling based upon identified criteria, and to build governmental economic policies on scientific grounds. Our conclusions and suggested measures are singular in respect of their content. They enable to evaluate objectively-based methodic grounds of the economic science anew. We believe, that the article would be of interest to a wide circle of researches dealing in methodology and economic modelling.

Keywords: crisis of economic science, scientific approach, economic paradigm, science methods, scientific schools.

\footnotetext{
${ }^{1}$ Dr. habil., Economics, Professor of the Department of Economics and Finance, Odintsovo Branch of the Moscow State Intstitute of International Relations of the Ministry of Exterior of the RF. 3 Novo-Sportivnaya 143000 Moscow Region, Odintsovo

${ }^{2}$ Dr. habil,. Economics, Professor, Department of Economics and Finance, Odintsovo Branch of the Moscow State Intstitute of International Relations of the Ministry of Exterior of the RF. 3 Novo-Sportivnaya 143000 Moscow Region, Odintsovo

${ }^{3}$ Ph.D., Economics, Assistant Professor of the Department of Economics and Finance, Odintsovo Branch of the Moscow State Intstitute of International Relations of the Ministry of Exterior of the RF. 3 Novo-Sportivnaya 143000 Moscow Region, Odintsovo

${ }^{4}$ Ph.D., Economics, Assistant Professor of the Department of Management, Odintsovo Branch of the Moscow State Intstitute of International Relations of the Ministry of Exterior of the RF. 3 Novo-Sportivnaya 143000 Moscow Region, Odintsovo
} 
Periódico do Núcleo de Estudos e Pesquisas sobre Gênero e Direito

Centro de Ciências Jurídicas - Universidade Federal da Paraíba

V. 8 - No 07 - Ano 2019 - Special Edition

ISSN | 2179-7137 | http://periodicos.ufpb.br/ojs2/index.php/ged/index

\section{Introduction}

The modern economic science has amassed plenty of contradictions that are unexplainable from the standpoint of science but have to be explained immediately in view of the global challenges. First of all, they have to do with scientific grounds of economic policy of the state. In fact, the economists are unable to provide them "limiting their discussions to special remarks without touching its erroneous grounds 5 ." Despite that, " ideas of the economists ... rule the world ... be they right or wrong 6 ."

We believe, that politicallyinduced development and implementation of economic policies by constantly changing liberal and neoliberal groups promoting the interests of ruling elites would sooner or later result in catastrophic economic, political, social and environmental consequences. It is already the case, that the "invisible

${ }^{5}$ R.I. Khasbulatov, To a New Economic Model [K novoy ekonomicheskoy modeli] // Segodnya i zavtra Rossiyskoy ekonomiki. Nauchno-analiticheskiy sbornik .: M. Iz-vo «Ekonomicheskoye obozreniye» 2009g. s. 3-18.

6 J.M. Keynes, The General Theory of Employment, Interest and Money [Obshchaya teoriya zanyatosti, protsent i hand" of economic markets would rather increase economic efficiency while the "invisible foot" of political markets would bring it down ${ }^{7}$. Proceeding from this, we regard explanation of the deepest recession of the economic science as the most topical task.

In the course of study, we analysed and classified scientific works of various authors including J.S. Mill, J.M. Keynes, I. Gilboa, E. Postlethwaite, L. Samuelson, D. Schmeidler, D. Colander, P.L. Kapitsa, O.S. Sukharev, P.S. Lemeshchenko, R.I. Khasbulatov and others - as regards substantiation of the need to improve the scientific approach, the problems in economic modelling and the need for a sound economic policy of the state; as well as A. Smith, J. Stiglitz, V.M. Polterovich, V.S. Avtonomov, P.E. Samuelson, A.A. Petrov, I.G. Pospelov, S.M. Menshikov, L.V. Kantorovich, V. Blaug, L.I. Abalkin and others - as providing a

deneg] / M. Izd-vo «Gelios ARV» 2002g. s. 350 .

${ }^{7}$ S.A. Afontsev, The Policy of Institutional Change: from Theory to Practical Recommendations [Politika institutsionalnykh preobrazovaniy: ot teorii k prakticheskim rekomendatsiyam] // Pod red. S.A. Afontseva. - M .: IMEMO RAN, 2013.s. 42. 
picture of the state of the posed problems and available solutions.

The main conclusions are set out basing upon findings contained in the works of Plato, M. Weber, V.S. Nemchinov, A.A. Zinovyev, R. Nureyev, K.K. Kumekhov, S.A. Afontsev.

\section{Materials and Methods}

The record shows, that implementation of ideas of the "classic" and "neo-classic" schools have not yielded the expected results because they cannot explain the nature and dialectics of economic phenomena and processes. This is revealed by comparison of the science's development with the "economic practice"». Many scientists realize the falsehood of the science's basic premises recommending not to be especially disappointed by that until their

8 P.S. Lemeshchenko, Problems of Development of Modern Economic Science [Problemy razvitiya sovremennoy ekonomicheskoy nauki] // M.1997. - № 3.s. 8.

${ }^{9}$ I. Gilboa, E. Postlethwaite, L. Samuelson, D. Schmeidler, Economic Models as Analogies [Ekonomicheskiye modeli kak analogii] // Voprosy ekonomikiM .: 2015. №4 s. 106-130.

${ }^{10}$ D. Colander et al. Financial Crisis and the Failures of the Modern Economic Science findings are "more or less precise", confirmed empirically.

Sometimes, theories developed against this background attribute systemic crises to "transcendental phenomena"10. Of course, such views and opinions have nothing to do with science because it is "only exploration of deep laws of the objective world serves the starting point for practical application of science ${ }^{11}$.

We believe, that this situation is to a great extend due to the inadequacy of the scientific approach and methods, particularly, in modelling of economic system, as well as to the lack of the effective mechanism of implementation of scientific research including mathematical models which are insignificant by definition as a concept of the economic models structure is absent. In particular, the widely used method of decomposition of economic systems

[Finansovyy krizis i provaly sovremennoy ekonomicheskoy nauki] // Voprosy ekonomiki M .: 2010. №6 s. 10-26.

${ }^{11}$ G.I. Ruzavin, Fundamental and Applied Studies in Structure [Fundamentalnyye i prikladnyye issledovaniya $\mathrm{v}$ strukture] Tsentr gumanitarnykh tekhnologiy. Informatsionno-analiticheskiy portal [Elektronnyy resurs] URL: http: //gtmarket.ru/laboratory/expertize/6202 (data obrashcheniya 18.01.2016). 
provides only for verification of functional variables of particular elements, at its best, and not of the system as a whole, which is due to the emergence of some of its elements.

To a great extent, this is because the scientific community adherent to the market ideology has been developing the methodology failing to meet many fundamental imperatives of the science. For example, there is no explanation to the following:

What are the basic imperatives of the economic science comprising the scientific approach? What is now represented as such, is, in fact, a mix of methods used to garner serve false pseudoscientific theories.

What is the main goal of the economy and its constituents as they function? To which extent do their goals correlate and what are the effects of their interaction? According to the market economy classics as well as the current practice, they do not coincide, to put it bluntly. This circumstance engenders many uncertainties for managing institutions as well for businesses and other entities.

What is the mechanism to implement scientific findings?
555

policy proceed from scientific perception or reality or political dogmas that are usually irrelevant to science?

Which of the elements or mechanisms of modelling has to be used as the basic criterion?

Despite all this, it has to be noted that applied economy and specifically econometrics have reached the highest level of organisation and efficiency due to informatisation and automation. At the same time, all those achievements have not been interpreted or explained theoretically.

Clearly, any further advances of the economic sciences are impossible without proper answers to the questions posed. Proceeding from the above, we have designed a sequence of actions to reveal the causes of the present critical state of the economic theory, as well as to explain them and suggest measures to overcome their negative influence, to include the following:

studying and evaluating theoretical grounds of formation and use in the course of exploration of the scientific approach;

studying the goals of the economy and its constituents; evaluating 
their compatibility and substantiating their interaction and influence on the state of economy as a whole;

exploring and evaluating implementation of scientific findings; exploring the modern methods of modelling economic systems to reveal the modelling criterion.

Al this enabled us to:

- word the scientific approach to economic sciences substantiating its elements, their hierarchy and relationships;

suggest the mechanism of implementation of scientific findings based upon the consistent utilisation of the three models: ideal universal one; ideal useful one; real functional one;

substantiate the need for economic models based upon the methodic substantiation of the modelling criterion defined by ourselves as the technological factor using spread lines of resource distribution.

12 S.I. Ozhegov, N.Yu. Shvedova, Explanatory Dictionary of the Russian Language [Tolkovyy slovar' russkogo yazyka] / Rossiyskaya akademiya nauk. Institut russkogo yazyka im. V.V.Vinogradova. - 4-ye izd., Dopolnennoye. $\quad-\quad \mathrm{M} \quad \therefore \quad$ OOO Tekhnologii», 2006. S. 492.

\section{Findings}

In the course of the study, having analysed the aforementioned sources we had singled out several paradoxes, i.e. phenomena that seem unbelievable or unexpectable ${ }^{12}$ from scientific viewpoint.

Paradox No. 1 - Economic science has no generally accepted approach

Scientific approach to economy appears as an "aggregate of principal ways and methods of solving problems aimed to obtain new knowledge as well as to generalise and deepen the understanding of the aggregate of facts and theories"13. Semantically, it is often identified with the method in the broadest sense including the "ways, instruments, the aggregate of exploration of natural and social phenomena"14.

From the very start, economic studies have been focused mainly on

${ }^{13}$ Science [Nauka] - [Elektronnyy resurs] URL: http://ru.science.wikia.com/wiki/ (data obrashcheniya 18.10.2017).

${ }^{14}$ A.A. Porokhovsky, Course of Economic Theory. Manual. $6^{\text {th }}$ Edition Corrected, Amended and Reworked [Kurs ekonomicheskoy teorii: uchebnik - 6-ye ispravlennoye, dopolnennoye i pererabotannoye izdaniye] - Kirov: «ASA», 2007g. s. 32. 
empiric materials. Generalised and systemic knowledge received by that laid the basis of new laws. Nobody cared for the need to reveal and substantiate the content of scientific approach being the foundation of any science.

The fact, that the lack of the unified approach makes the economic science handicapped was once noted by one of the greatest English economists J.S. Mill. He did not understand why the generally recognized certainty of science "is by no means doubted due to the lack of substantiation of their premises?" $\mathrm{He}$ revealed the "paradox" economic science has until now. "Instead of being a starting point for a chain of proofs supporting the rest of the science's building", scientific principles become "the remotest link of that chain"15. We believe his words to be extremely clear: a system of imperatives of the economic science shall be worked out to

15 J.S. Mill, The Principles of Political Economy with Some of Their Applications to Social Philosophy [Osnovy politicheskoy ekonomii $\mathrm{s}$ nekotorymi prilozheniyami $\mathrm{k}$ sotsial'noy filosofii] / Dzh.S.Mil': [per. s s ang., biograf. Ocherk M.I.TuganBaranovskogo] .- M.: Eksmo, 2007.s.989. 16 P.L. Kapitsa, The Future of Science. Speech at the International Symposium on Science Planning on 20 September 1959 systematise it and put it to the path of objectivity.

Not accidentally, P.L. Kapitsa noted in his speech at the International Symposium on Science Planning on 20 September 1959 that "social sciences have not recognized unified laws..." because "the social science has no objective approach. It is until it is created that social sciences will be developing with great difficulty" ${ }^{\prime \prime}$.

Modern authors use to reduce the lack of scientific approach to recognition of the methodic difficulty to define "the subject of economic science as well as its method and verification of economic knowledge and creation of the theory"17. The matter of identity of "scientific approach" and "scientific methodology" is seen by them in individual preferences that are, however, cannot influence the result of research, recognizing "arguments considered scientific ones ... as an instrument of

[Budushcheye nauki. Rech' na Mezhdunarodnom simpoziume po planirovaniyu nauki Praga, 20 sentyabrya 1959 g.] // «Mir nauki» 4, № 3-4, 2 (1960).

${ }^{17}$ O.S. Sukharev, Methodology and Abilities of the Economic Science [Metodologiya i vozmozhnosti ekonomicheskoy nauki] Monografiya. / O.S.Sukharev- M .: KURS: NITS INFRA-M, 2013. S. 43. 
persuasion" [ibid.]. They clearly speak about the "methodologic pluralism" which this science is doomed to in their opinion. Obviously, the power of the science is reduced to the power to "persuade" whereas it is those "scientific arguments" seen so differently by the authors that are arguable.

Not accidentally, Academician of the Russian Academy of Science, V.M. Polterovich, understanding the deep crisis of the modern economic theory calls to a "rewording of its main purposes and changing the research style" because "theoretic facts are being amassed witnessing the fundamentally limited nature of its methods." At the same time, he stresses that despite the fact that the "economic theory has become older ... its methodic problems have only deepened" ${ }^{\prime 19}$. He readily acknowledges that sees no "clear ways to exit the crisis" calling to a discussion that "would promote the search of them" [ibid.].

18 V.M. Polterovich, Crisis of Economic Theory [Krizis ekonomicheskoy teorii] [Elektronnyy resurs] URL: http: //www.nbrilev.ru/krizis_economic_theory_. htm (data obrashcheniya 18.10.2016).

19 V.M. Polterovich (1990), Economic Equilibrium and Economic Mechanism [Ekonomicheskoye ravnovesiye i
To clear up the causes of the crisis, Academician V. Avtonomov, proposes to build the scientific approach around acknowledgement of the two parallel "canons" of the economic science. "The first canon is connected with the strive towards universal truths" ...oriented on the "natural scientific ideal" formed by views of the physiocrats, classic political economy and neoclassics.

The core of the second canon built "from the bottom up" is experience and its main goal is to "create an immediately useful economic theory" 20 . Besides that, he discovered another aspect of the lack of scientific approach being the large gap... "between theoretic and applied economics" [ibid.]. Unfortunately, he does not explain the mechanics of transition from the first canon to the second and vice versa which is why any arguments are pointless.

The fact, that "in the economic science the basic premises are false" 21

khozyaystvennyy mekhanizm] - M .: Nauka. S. 256.

${ }^{20} \mathrm{~V}$. Avtonomov, Abstraction is the Mother of Order [Abstraktsiya - mat poryadka] // Voprosy ekonomiki. M.: NP «Voprosy ekonomiki» №4 2013g. s. 4-24.

${ }^{21}$ Cited by: I. Gilboa, E. Postlethwaite, L. Samuelson, D. Schmeidler, Economic Models as Analogies [Ekonomicheskiye 
was also recognized by Nobel laureate M. Friedman and others.

Paradox No. 2 - Economic science has no clear mechanism of implementation of theoretic research into practice

Modern research implementation mechanisms are arbitrary being designed in accordance with dominating paradigms and specific goals. It is generally accepted, that their objectivity is judged upon by their ability to fit in the reality without disturbing or imposing themselves on it. Not accidentally, P. Samuelson compared this state of the economists with that of "trained athletes" never taking part in "competitions",22.

In most instances, implementation of a research requires repetition of some pre-studied experience that once had produced a high result. However, every time source parameters are obsolete by the moment they are used which makes repetition of such experience useless.

modeli kak analogii] // Voprosy ekonomikiM .: 2015. №4 s. 106-130.

22 P.E. Samuelson, 1947. Printed in 1983. Fundamentals of Economic Analysis [Osnovy ekonomicheskogo analiza] Garvardskiy universitet.

${ }^{23}$ A.A. Petrov, I.G. Pospelov, Mathematical Modelling of the Economy of Russia
For example, let us consider the studies of Academicians A.A. Petrov and I.G. Pospelov. By analysis of real economic relations and "superposition on them of the postulates" of the model of behaviour of economic agents "firms, banks, population, owners, state, central bank, foreign trade institutions" they created "models reflecting internal mechanisms of economic development and the influence of macroeconomic policy on them"23. They claim to have been able to reproduce the "complex dynamics of about 20 fundamental macroeconomic indicators over 16 quarters 2003 - 2006, evaluate the shadow turnover etc."

Even if we believed their conclusions as true, that would not means that the knowledge and experience obtained by them could be used in any decision-making. Firstly, there are no sufficient methodic grounds, for example, of the choice of an adequate model of the "economic agents", research base etc. Secondly, the

[Matematicheskiye modeli ekonomiki Rossii] / Vestnik Rossiyskoy akademii nauk. 2009. T. 79. Net 6. S. 492-506. [Elektronnyy resurs] Rezhim dostupa: http://www.ras.ru/FStorage/download.aspx? $\mathrm{Id}=\mathrm{d} 4 \mathrm{f} 4 \mathrm{~d} 061-28 \mathrm{~d} 5-4 \mathrm{c} 7 \mathrm{c}-8 \mathrm{a} 65-$

ef8e1e3ac11(data obrashcheniya 02.06.2017). 
mechanism of practical use of their findings is missing.

We consider this approach to be fundamentally erroneous also because every "try" of the "experience" on to particular circumstances makes theory and practice merge. Under such circumstances, an economist is, actually, a "scientific decorator" 24 of some positive experience made possible by lobbying of someone's group interests or insider information and not by scientific research. Among other things, this approach provokes conflicts of interests of the ruling elites wishing to increase their wealth and the society facing global challenges including scarce resources, migration, environmental, medical and educational crises etc.

The most illustrative of efficient use of scientific results may be the study of the Nobel laureate, L.V. Kantorovich (1975, For the Contribution to the Theory of Optimal Distribution of

${ }^{24}$ K.K. Kumekhov, Critics of the Classic Macroeconomic Modelling Theory [Kritika klassicheskikh teoriy makroekonomicheskogo modelirovaniya] // M .: Vestnik MGIMO Universiteta. 2015. №5 (44). S. 181-189.

${ }^{25}$ S.M. Menshikov, The Topicality of the Economic Model of L.V. Kantorovich Nowadays [Aktualnost ekonomicheskoy modeli L.V. Kantorovicha v nashe vremya]
Resources). Unlike the "extreme liberalism theory"25, Kantorovich's concept was created for planned economy. His proposals are feasible only where the state "is able to definitely influence economic development." [ibid.]

Although his concept of stateapproved optimal price resulted rather from feeling than from methodological premises, it had long been an instrument of finding optimal and balanced prices allowing to keep the economy proportional. Despite the fact, that he "put the idea of economic optimisation on a solid scientific base, discovered a separate class of production and economic tasks and developed methods to solve them"26, his theories failed to save the socialist model of economy from disruption due in large measure, to the lack of theoretic comprehension and clear implementation mechanisms.

[Elektronnyy resurs] Rezhim dostupa: http://www.fastcenter.ru/smenshikov/Kanto rovich.htm. (data obrashcheniya 22.06.2017).

26 L.V. Kantorovich, The Problems of Effective Use and Development of Transport [Problemy effektivnogo ispol'zovaniya i razvitiya transporta] [Internet-sayt] = ru (data obrashcheniya 12.12.2017). 
Paradox No. 3 - Goals of the economy and its constituents differ

To substantiate the validity of this concept, we use two definitions of the goal of economy. W.S. Jevons puts it as follows: "Given, a number of people with different needs and production abilities owning land and other resources. We require to define the way of utilisation of their labour maximising the utility of the product"27. The second one was given by P.A. Samuelson and W.D. Nordhaus who saw the following three problems: Which how much goods to produce? How to produce goods? Whom to produce goods for? ${ }^{28}$. Similar definitions are quite enough to conclude that any national economy has to provide the population with particular goods, services and living conditions measured in kind. For example, how much food, other goods, services etc. shall be produced. They all are produced by entities having making of profit - i.e. monetary equivalent of economic benefits - as the main goal of their activity. It is known, that money has no

\footnotetext{
${ }^{27}$ M. Blaug, cited by: M. Blaug, Economic Theory in Retrospect. Cambr.;N.Y. 1983. P.310.

28 P.A. Samuelson, W.D. Nordhaus, Economics. Fifteenth Edition [Ekonomika.
}

user value giving only the formal right to receive some goods on the issuer's territory.

Such dichotomy is hard to explain from the point of view of the academic science. Although the emergency effect may exist in some sectors, it is not fully applicable to the economy as a whole. For example, it can be stated for medicine, education, law enforcement, military and the economy as a whole, while particular industries of the real economy do not reveal it.

The negative impact of this paradox on efficiency of the economy as a whole depends on economic policy of the state and its ability to make all its constituents contribute to reaching the common goal. Socialist economy based upon planning gave everybody benchmarks to be complied with in kind. At the same time, the principle of democratic centralism admitted correction of plans given out "from the top" which did not mean the full economic independence. Most importantly, planned indicators

Izdaniye pyatnadtsatoye] - M. Iz-vo KnoRus 1997g. s.40. 
comprised one and the same inter-related system at all levels.

Under the market economy based upon the primacy of private initiative with minimal influence of the state on economic processes, such unification of goals is impossible.

Paradox No. 4 - Economic policy of the state is built upon political views

Economic policy-making based upon dogmas rather than opinions of scientists is inherent to the socialist and the capitalist model alike. The socialist one is based upon the formational approach of K. Marx. According to it, any social and economic formation has two main components - basis and superstructure - the first being the society's economy formed by production forces and relationships. The superstructure is the state as well as political and social institutions ${ }^{29}$.

The views of $\mathrm{K}$. Marx were influenced by English political economy classics and economic practice. They were accepted by the scientific community although specific matters of

\footnotetext{
${ }^{29}$ L.I. Abalkin, From Economic Theory of the Long-term Strategy Concept [Ot ekonomicheskoy teorii do kontseptsii
}

the economic were not researched either by himself or his associates. In the time of the Soviet Union and formation of the world socialist system, the theory was significantly enriched by Marx's followers with many practical issues. Thus, the USSR and other countries of the so called Socialist Community realized a new type of economy transformed in economic systems based upon common ownership of means of production. Instead of "competition" and "invisible hand of the market", the planned production was implemented to "satisfy the material and spiritual needs of the society".

To some extent, planned production contributed to systematisation of economy because it required balance development of basic industries to stabilise the system as a whole paying regard to the technological factor involving related sectors into the process.

At the same time, studying the ostensible variety of national economies oriented on the socialist model involved economic practices only without their theoretical comprehension. In fact, the

budushchego strategiy] // Voprosy ekonomiki. M .: 2010. №6 s.4-10. 
theory described an "ideal object not related to the real economy of the socialist countries being, though, compliant with political tenets" 30 .

In the end of the $\mathrm{XX}$ century, the socialist project was actually completed despite the ambiguity of its results.

As regards the lessons of the second, capitalist experiment, they are "much less definite" 31 . All modern economic schools sticking to the market ideology proceed from the postulate, that "by nature, economics is an empirical science" ${ }^{, 32}$ and derive their theories from economic practices.

According to the Russian as well as to the foreign experience, governments responsible for development and implementation of economic policies are constituted in two

${ }^{30} \mathrm{~V}$. Avtonomov, Economic Theory in the Institute of the World Economy and International Relations [Ekonomicheskaya teoriya V IMEMO: sovetskiy period] // Voprosy ekonomiki M .: 2016. №11 s. 117135.

31 J. Stiglitz, Failures of Corporate Management in Transition to the Market [Neudachi korporativnogo upravleniya pri perekhode k rynku] // Ekonomicheskaya nauka sovremennoy Rossii. № 4, $2001 \mathrm{~g} \mathrm{~s}$. 108.

32 P.A. Samuelson, W.D. Nordhaus, Economics. Fifteenth Edition [Ekonomika.
563

principal ways depending on the degree of parliamentarian participation in the process. The first one does not use parliament and is typical for presidential republics, the second is specific to parliamentarian rule where the lower house majority party or coalition is entitled to form the government ${ }^{33}$.

Irrespective of the way of creation of the government and its structure, scientifically, there is the question of the expediency of such procedures. In our opinion, economic policy may not be a subject of political bargaining. It should be based upon scientific knowledge with view to the real economic situation in the country. ${ }^{34}$. Obviously, the process shall be managed to professional economists and not politicians who often do not have even a slightest idea of it. It is also obvious, that

Izdaniye pyatnadtsatoye] - M. Iz-vo KnoRus 1997g. s.40.

${ }^{33}$ Procedure of Formation and Structure of Governments of the Foreign Countries [Poryadok formirovaniya i struktura Interneta [] [Elektronnyy resurs] URL: http://www.studylaw.narod.ru/mishin/mishi n_10_2.htm (data obrashcheniya 18.012.2017).

${ }^{34}$ K.K. Kumekhov, The Concept of Sectoral Structure in Modern Theory of Economy [Kontseptsiya otraslevoy struktury $\mathrm{v}$ sovremennoy teorii ekonomiki] // Natsional'nyye interesy: prioritety i bezopasnost'. M. №43 (280) 2014.s.38-51 
they use their powers to create an ineffective economic system pursuing pecuniary interests of som "rentoriented" lobbying groups ${ }^{35}$.

The scale of inefficiency and squander increase by times to the lack of coordination between different branches of power, oligarchic structures, secretive decision-making by bureaucrats.

\section{Paradox № 5 - Economic} science lacks scientific substantiation of modelling criteria

Approaching the economic science scientifically takes reasoned choice and application of any research method. To model economic systems at different management levels, such a method may be the basic modelling criterion. Modern science does not have this concept though no model is developed without it. In our opinion, modelling criterion is a factor chosen reasonably to be the system to be the core of the system communicating with all its elements and, by this communication, ensuring its integrity and improvement

\footnotetext{
${ }^{35}$ A.D. Radygin, R.M. Entov, [«Провалы государства»: теория и политика] // M.: Вопросы экономики. 2012. №12. С. 4-30. ${ }^{36}$ V.N. Cherkovets et al., The World History of Economic Thought in 6 Volumes
}

under changing circumstances. Most often, modern economic schools choose such basic modelling criteria as balance between supply and demand or production and consumption, lines of behaviour etc. They are based upon the method of decomposition which, by definition, pays no regard to the state and effects in the interaction of all elements of the system. Moreover, such models are usually static ignoring different time modes. Management decision using such modelling are based on extrapolation of experience on to future events or on comparison of forecast data obtained by the modelling with actual ones. The futility of such approach has been confirmed by authors of these models themselves.

For the first time, the works using elements of modelling were published in the XVII century by F. Quesnay, a member of the Physiocratic school. In his Economic Table (1758), he attempted to reflect the process of "reproduction of origin of income" 36 . It is worth noting, that none of his

[Vsemirnaya istoriya ekonomicheskoy mysli v 6 tomakh] / V.N.Cherkovets, Ye.G.Vasilevskiy, V.A.Zhamin, I.P.Faminskiy i dr.M .: Izd-vo «Mysl'» 1987.Tom 1. - 606s. 
followers as well as the followers of any other known schools presents economic models schematically. Besides that, his conclusions from the Economic Table may justly be attributed to the most important ones in respect of not only their content but the form of presentation of findings. Having introduced the "fetus of future economic models" to the macroeconomic grid [ibid.] he reasonably noted, that "reproduction and sales can be uninterruptable only subject to the certain proportions of economic development." [ibid.]

Without questioning the innovative merits of Quesnay, it is worth pointing out one of the main shortcomings of this theory - the absence of any modelling criterion, without which the inclusion of "farmers, fruitless class and land owners" in the "economic grid"37 as well as the ways of their interaction has no good reason.

The leader of the Lausanna School L. Walras adhered to the "closed mathematical model" of general economic equilibrium based upon the principle of subjective utility provided

\footnotetext{
${ }^{37}$ V.S.Nemchinov, Economic Mathematical Methods and Models [Ekonomikomatematicheskiye metody i modeli] /
}

that all participants of production divide in two groups: the owners (of land, labour and capital) and entrepreneurs. He did not single out the main principles of that model without which its elements, links and interactions cannot be identified. Taking some equilibrium as the modelling criterion would not allow to build the model as a whole.

An improved version of the closed economic equilibrium model was developed by R. Frisch. The recognized "pioneer of econometrics based his general market equilibrium model on the choice of the final goals - maximisation of public utility function and definition of target indicators, which cannot also be regarded as modelling criteria being target figures. Frisch's principle of acceleration disclosing the influence of the level of investment and income on income growth cannot be regarded as such either.

In his work "The General Theory of Employment, Interest and Money" (1936), another classic J.M. Keynes based the macroeconomic model on selection of "such variables that can

\footnotetext{
V.S.Nemchinov

Izdatelstvo:

"Gosudarstvennoye sotsialnoekonomicheskoye izdatelstvo" 1962M. 412 s.
} 
be consciously controlled by the central government within the economic system we live in." It is accepted, that he had succeeded at establishing "quantitative and functional dependencies of the capitalist production, the quantitative laws of connection between the integral economic values: investment and national income, investment and employment, national income, consumption and savings, total quantity of money in circulation, price levels, salaries, profits, interest etc.. ${ }^{38}$.

However, in his studies Keynes repeated the mistakes of his predecessors. In particular, all his models are based upon the mathematical equilibrium of demand for and supply of production services which cannot balance the model as a whole. In this case, only a mechanism of interaction between value (product) and price (cash flow) etc. can be talked about.

Thus, the works mentioned above as well as those of other renown authors of economic models such as those of Samuelson-Hicks, ArrowDebreu etc., lead to the conclusion that

${ }^{38}$ J.M. Keynes, Introduction to the series: Cambridge Economics Handbooks [«Vvedeniye» k serii Spravochniki no modelling criterion was considered by any of them as the most important component of modelling. Emphasising the mathematic apparatus they actually left the global structure of the economic model aside.

\section{Discussion}

The unconditional principal goal of the economic science is to work out a generally accepted approach to serve as the basis of the new economics paradigm. Without doubting the necessity of different views of processes and phenomena, their objectivity shall be assessed through the lens of the generally accepted scientific approach.

In the terms of A.A. Zinovyev, a scientific approach has to be based "first of all, on subjective impartiality, i.e. the experience of things irrespective of the researcher's positive or negative attitudes to them and without regard to the findings serving interests of any classes of people." However, in his opinion, this "principle is constantly

Kembridzhskoy ekonomiki] Tsitiruyetsya Sergiyenko L.V. Ekonomika [Elektronnyy resurs] URL: http: //nashaucheba.ru/v (data obrashcheniya 10.12.2017) 
violated or even consciously ignored"39 in social science despite the fact that "interpretation of empirical factors may be considered scientific" and their "interpretation becomes objective and can be generally accepted" subject only to compliance with the scientific approach.

Against this background, we consider it incorrect to consider the terms "scientific approach" and "scientific method" equivalent and of the same level, because the term "scientific approach" is broader to include also methodology. For the economic science, scientific approach consists, in our opinion, of a set of elements shown in Diag. 1 with hierarchic relations between them. The determinative element of scientific approach is its goal which "has to specify what this science serve to" ${ }^{" 40}$.

Given the main goal of the constituents (maximisation of profit) and the state (financial support of the institutions and social responsibility), the goal of the economic theory appears as definition of conditions that would make it possible, and that of the practical economy comes to the practical fulfillment of these goals under specific circumstances.
${ }^{39}$ A.A. Zinovyev, Ideology of the Party of the Future [Ideologiya partii budushchego] M .: Algoritm, 2003 g. [Elektronnyy resurs] URL: http://conflictmanagement.ru/nauchnyiypodhod(data obrashcheniya 10.12.2015).
${ }^{40}$ K.K. Kumekhov, A.K. Kumekhova, On the Problems and Ways of Development of the Modern Economic Theory [O problemakh i napravleniyakh dal'neyshego razvitiya sovremennoy ekonomicheskoy teorii] // Natsional'nyye interesy: prioritety i bezopasnost'. M. №20 (209) 2013.s.55. 


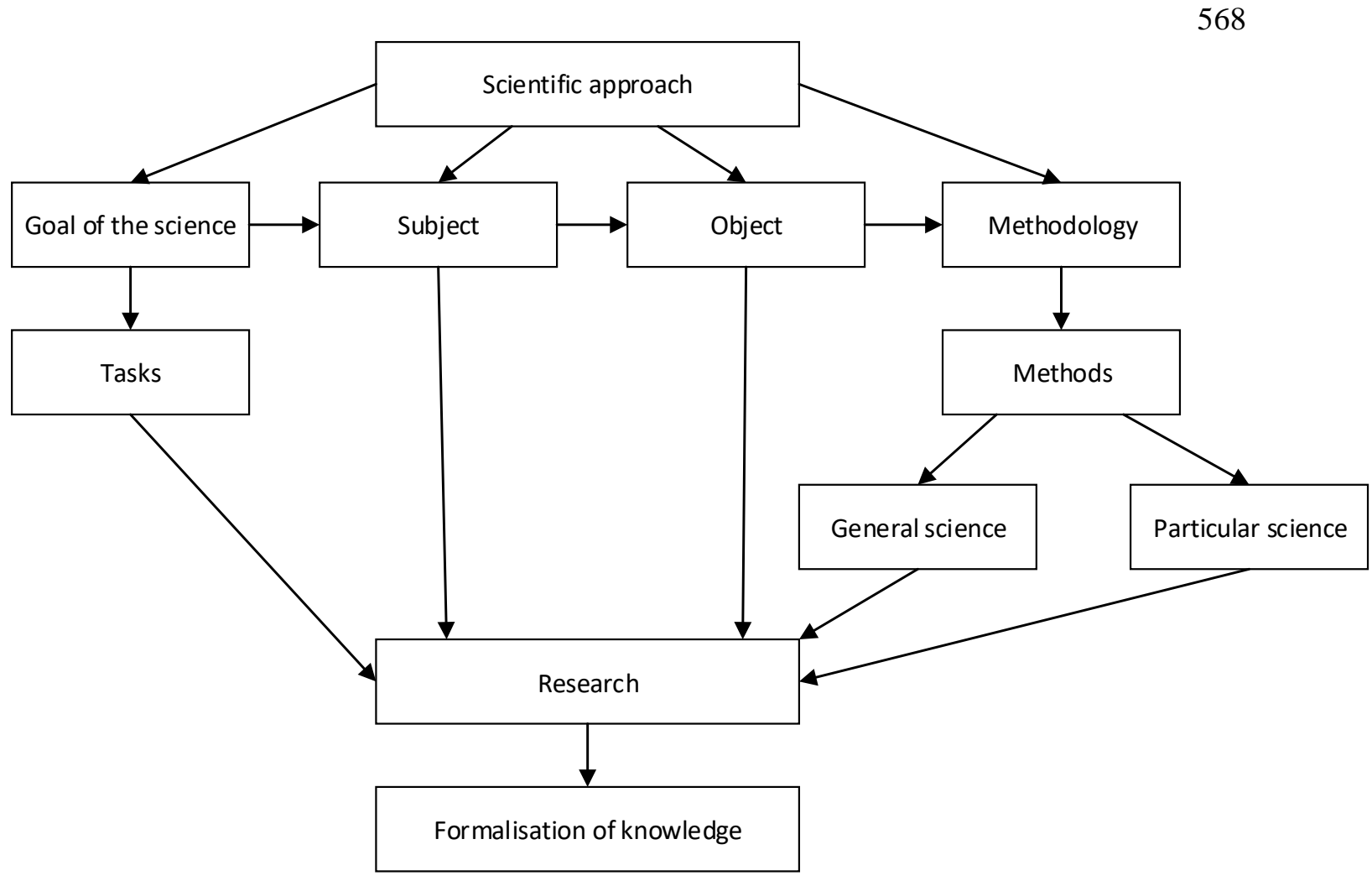

Diagram 1 - Elements of scientific approach to economy and relations between them

In our opinion, the content of scientific approach in theory and applied economy should be distinguished. They differ, first of all, in their goals: the first one explores the subject with no practical tasks freely while the second one strives to the practical effect by analysing and evaluating the real-life economic model. Proceeding from this, scientific approach to economy shall be viewed in these two forms: as a cognitive and applied one. (see Diag. 2). Each of them comprise a

41 G.D.Zhangissina, Methodology of Development of Lecturing Materials for the number of elements connected consecutively. Different in respect of their content, they are parts of the same algorithm leading to the main goal.

The main goal determines the content of research concepts. In economics, a research concept is seen as an "integral and logically consistent system of views united under some general idea and aimed to the goal(s) of the research"41. Such definition does not, however, reflect the content of the [Metodika razrabotki lektsionnogo materiala 
category to the full extent. Along with the "system of views" and "ideas", a concept must include the object and the subject of research. In economics, it is the starting point of modelling determining the subject, the object and the methodology of the science. According to the accepted paradigm, all these are the elements of the same level. In the course of research, the goal creates a set of particular tasks and the methodology is made specific by particular methods. In aggregate, these elements provide for the objectivity of the research the findings of which are them presented in a formal way.

The least studied element of scientific approach is the choice of the object in both instances. According to established rules, the subject is the same for the theoretic and applied studies.

In our opinion, such commonness of the subject does not allow to develop theory and practice as independent lines of research. Most importantly, it does not allow to work out an efficient research implementation mechanism. po distsipline «Osnovy nauchnykh issledovaniy»] [Elektronnyy resurs] URL: http:
//www.rusnauka.com/14_NPRT_2010/Peda gogica/67171.doc.htm (data obrashcheniya 18.01.2016). 
Periódico do Núcleo de Estudos e Pesquisas sobre Gênero e Direito Centro de Ciências Jurídicas - Universidade Federal da Paraíba V. 8 - No 07 - Ano 2019 - Special Edition ISSN | 2179-7137 | http://periodicos.ufpb.br/ojs2/index.php/ged/index

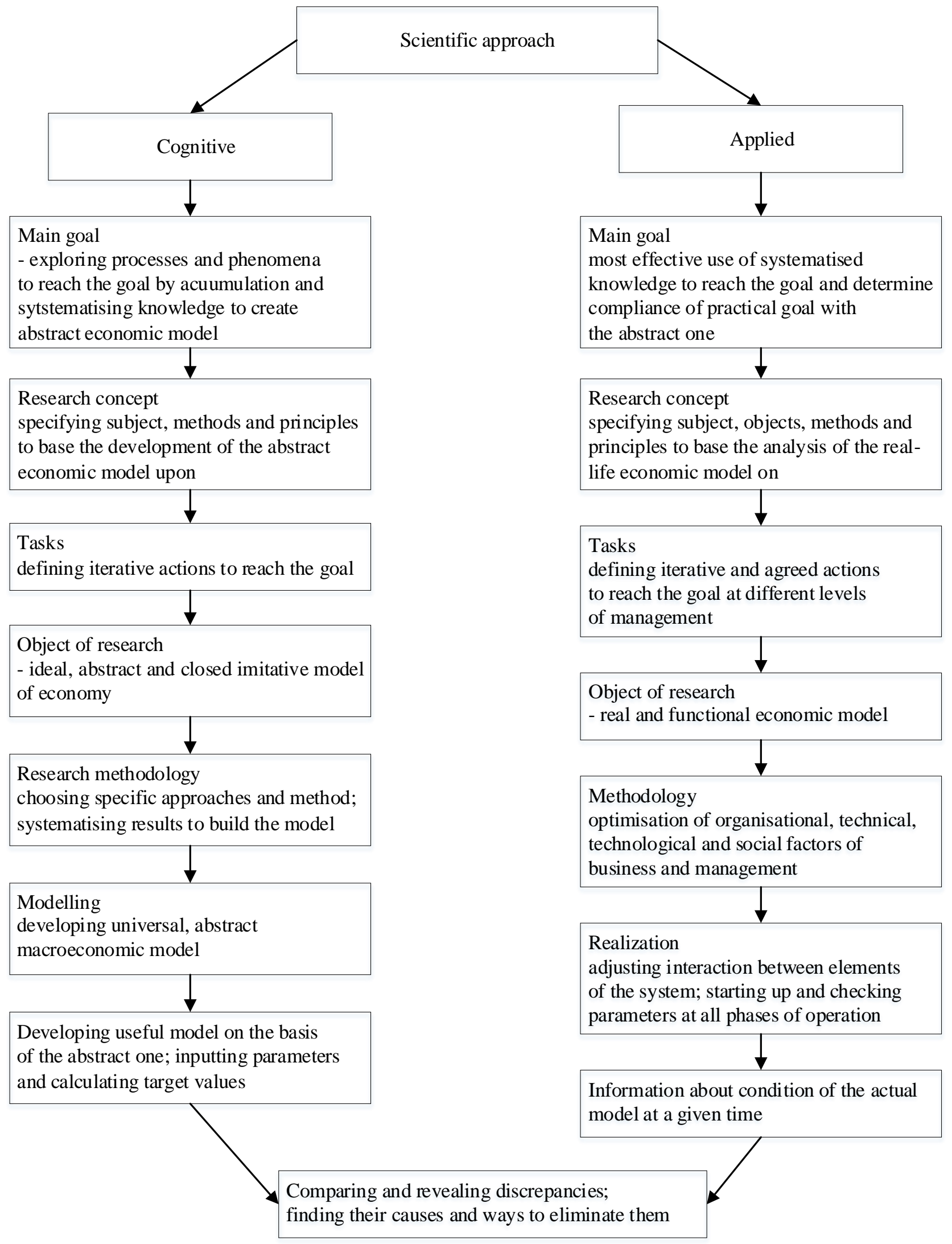

Diagram 2-Scientific approach in dependence of the line of research 
That is why we suggest to consider the universal, abstract and ideal macroeconomic model as the object of research. The content and structure of this model is available at library sites ${ }^{42}$. Conceptually, as an object of economic theory, this model is based on the latest achievements of science and best practices of organisational development, management, technology and equipment. Being static by nature this model provides (using qualitative and quantitative input parameters) the basis for the useful model to be applied to a real system (of a state, region or business entity). This model is also static and is designed to reach the best possible result. Such a model must be an ideal one reflecting the best possible efficiency for given economic system in specific circumstances.

For the applied model, we suggest a real example. To make it compatible, it has to be built according to the same rules and principles as the useful model. Its input shall reflect the presence and the use of available resources. "Inside" the model, the paths

\footnotetext{
${ }^{42}$ K.K. Kumekhov, Theoretic Substantiation of Two-level Structure of the Macroeconomic Model [Teoreticheskoye obosnovaniye dvukhurovnevoy konstruktsii
}

of resources over processing phases shall be shown, and at the "output" shall be the real consumption of finished products and services.

Proceeding from the technology of passing the resources over processing phases, the main goals is to establish interaction of constituents of the system, their launching and control over technological parameters at all phases of processing.

Our view of the scientific approach allows to single out the basic modelling criterion by which all macroeconomic models shall be made. It is the technological factor. After having analysed the evolution of productive forces retrospectively, it is clear, that technologies have always been the main driver of the progress [ibid.]. The theoretical basis of this choice is provided by scientific concepts of productive factors, economic processes, connections and relations between economic entities and institutions, goalsetting etc.

As the central link of the technological factor a spread line shall be

makroekonomicheskoy modeli] // Modeli, sistemy, seti v ekonomike, tekhnike, prirode i obshchestve. 2017. №2 (22) s. 69-87. 
used representing all the possible variants of use of the natural resource at all processing phases embodied in specific products expressed in money and in kind.

As the basic criterion, technological factor enables to reconcile processing technologies with advances of fundamental science, technics and technology.

\section{The lack of research} implementation mechanism is due to the incorrect understanding of the empirical method. On the grounds this understanding, processing of a large data range leads to a conclusion which becomes invalid as soon as the external conditions change. The non-scientific nature of such practice is evident. Proceeding from this, we suggest our own research implementation mechanism illustrated by Diagram 3. It
572

can be successfully used at both microeconomic and macroeconomic levels.

It consists of five elements connected cyclically, the first of them being an ideal and universal economic model.

It embodies all advanced ideas and achievements in technics, technology, information science and organisation of production of material and other goods for the society. It is a kind of reference economic model applicable of all economies. It includes the whole volume of known resources and multi-million combinations of their use augmenting with new scientific advances. The output of this model shows the best possible result in respect of quantity and efficiency. The source of these changes are empiric and fundamental studies.

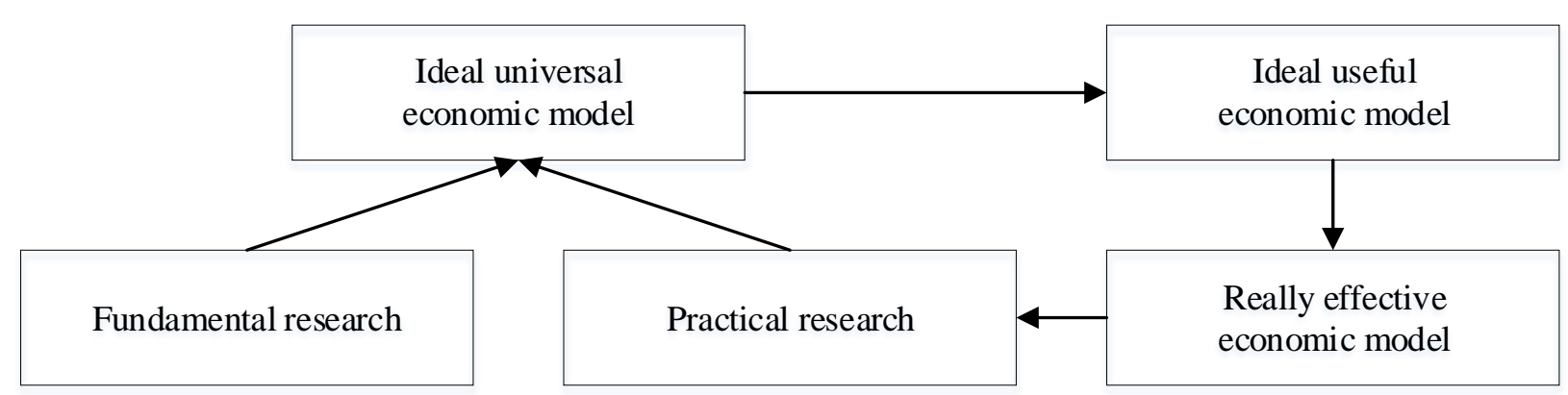

Diagram 3 - Implementation of research results 
The ideal and universal economic model is intended for development of the useful model for a particular economy. It differs from the universal model in that it proceeds only from recourses available to a particular state. The usefulness of such model is that it allows to determine the best possible result at the output.

Built by the same rules using empirical date with regard to the time lag, the real model would show actual efficiency. Comparison of the real and useful models would reveal discrepancies indicating weak point to improve the real model making it more stable in future.

This scheme is also indicative of the fact that each country's economic model is unique and singular because of its location and resource potential. This approach revealed also connections of the economic science with technology and other social sciences. Moreover, fulfillment of this approach allows to bring the accumulated knowledge to the universal economic model. Impartiality and objectivity of this model enables transition of the economic science from subjective theories creating and justifying uncertainty to the economy of objective theories harmonising processes and phenomena inside economic systems as well as in their interactions with the outside world.

As it was already noted, the fact that the goals of constituents of the economy do not coincide with those of the economy as a whole is unexplainable scientifically. To make sense of this, let as answer why the information is not published about the following:

the need of the population for goods and services in kind;

- the extent to which such needs can be satisfied out of domestic and external resources;

the number and capacity of enterprises required to ensure self sustainability etc.

It is the government itself that shall be interested in answers to these questions using all available instruments to the benefit of the population. As early as in 1776, Adam Smith recommended to do so "restraining competition in some industries... and strengthening competition in others... as well as restraining the free transition of labour and capital from one industry to another 
and from one place to another"43. Of course, such regulation was based on the necessity to take account of the population's need for particular goods measured in kind and not in money. The information system of that time complied with those goals.

In the time of globalisation, informational function of the state in the economy is fulfilled via national accounts. Created according to the principles of the European System of Integrated Economic Accounts ${ }^{44}$ they reflect the state and results of the economy as a whole. National accounts is a system of inter-related statistic indicators represented as tables describing macroeconomic processes. All indicators are presented in monetary terms which gives an incorrect picture of national wealth and goals of participants of economy. Given the present condition

43 A. Smith, [Issledovaniye o prirode $\mathrm{i}$ prichinakh bogatstva narodov] [Elektronnyy resurs] URL: http://www.eklit.org/smit012.htm (data obrashcheniya 18.01.2018). of the economy of the Russian Federation, this situation is degrading because it does not provide information for efficient managerial decisions.

For example, it is hard to compare the national wealth of Japan with their 126,4 million people with that of Russia with its 146,8 million people. It is accepted, that Russia is many times poorer than Japan because the latter's GDP is $\$ 4,513.75$ billion while the same of Russia is only $\$ 1,267.55$ billion $^{45}$. We believe, that only physical measures shall be used to measure national wealth including such as area, potential resources, location, production of most important products in kind etc. Here, the need for the state regulation of use of that potential is worth noting. Businesses shall be stimulated towards physical production. Any system cannot be

${ }^{44}$ Resolution of the State Committee for Statistics of the RF of December 31, 1997 No. 99 on Approval of the Regulations on the Administration of National Accounts [Postanovleniye Goskomstata RF ot $\begin{array}{lllll}31.12 .1997 & \mathrm{~N} & 99 & \mathrm{Ob} & \text { utverzhdenii }\end{array}$ Polozheniya ob Upravlenii natsional'nykh schetov] - [Elektronnyy resurs] URL: http://www.bestpravo.ru/rossijskoje/ljzakony/o5b.htm

${ }^{45}$ List of Countries by GDP [Spisok stran po VVP 2017, v \$ mlrd.] [Elektronnyy resurs] URL: http://investorschool.ru/rejting-stranpo-vvp-2017. 
efficient if the goals of its constituents do not coincide or are incommensurate.

In competitive economy where business entities pursue monetary profit only, they strive to abnormal profits. Sooner or later, some of them succeed and their financial capacity is used for political rather than economic purposes. They create centres of power manifesting themselves as political parties imposing specific views. As a rule, such parties are created for further enrichment of their beneficiaries. Accordingly, under this conditions, the economic policy of the state is determined by political views.

Disposing of unlimited financial resources, such centres of power are capable of exerting decisive, and usually negative, influence on culture, thinking and lifestyle. Given the uncontrollable growth of population and shrinking resources, it appears to be a dangerous game with unpredictable consequences.

Scientifically, this situation can be overcome by abandoning of the vicious practice of political formation of

\footnotetext{
${ }^{46}$ Plato. The State. Source: Plato. Collected works in 3 Volumes [Platon. Gosudarstvo. Istochnik: Platon. Sobraniye sochineniy v $3-$ kh tt.] T.3 (1). - M., 1971 g.
}

575

governments leading to patrimonial economic models described by $\mathrm{M}$. Weber who determined, that under patrimonialism, the mainstay of power was the "management apparatus and military formations acting as instruments of personal power" enabling the master "sometimes to ignore tradition." Presently, the same system serves some centres of force that agree upon the use of such force to their common benefit.

In our opinion, in this situation the ideas of Plato that the state shall be governed by intelligent people in the know $^{46}$ shall be actualised. These ideas have been developed by Samuel Haber, Donald Stabile and other authors having noted discrepancies between physical and monetary efficiency. They have substantiated that "those who think only about profit" when "prices of commodities are changed by market forces" 47 break "precise calculations of the engineer. As a result, the engineer loses control over the projects and has to reconsider his plans constantly." It was certainly T. Veblen who "contributed really greatly to the line of research

\footnotetext{
47 Weber M. Wirtschaft und Gesellschaft. Tubingen, 1976. S.133, 134.
} 
presently called institutional economy having shown the brightest example of the inter-disciplinary approach to the analysis of economic relations" ${ }^{\prime 4}$. At the same time, his theories were based on the sensual perception of economic processes and phenomena without due substantiation of the scientific approach and the very structure of the macroeconomic model.

The concept of scientific approach and economic models presented in our article may be used as a theoretical background of technocratic ideas allowing to quit the vicious practice of political mechanisms of government and economic policy.

\section{Conclusion}

The novelty of our study is that we discerned several paradoxes of the economic science commonly ignored due to the overall mathematisation and informatisation although their content and causes are unexplainable scientifically. In the course of the study we explained the nature of those paradoxes and revealed their influence on the economic science.

\footnotetext{
${ }^{48}$ R. Nureyev, Thorstein Veblen: a Look
} from the XXI Century [Torsteyn Veblen:
To overcome this influence we: specified and systematise the scientific approach to economy proposed to be considered as cognitive and applied one. In our opinion, this division allows to accumulate and systematise the knowledge of economic processes and phenomena using it for greater efficiency of the real-life economic systems;

- suggested the use of results of this modelling allowing to avoid the trap of time modes depriving from an opportunity to correctly extrapolate retrospective modelling on perspective models. Our research implementation mechanism includes all its elements and their interaction;

substantiated the need for legislative regulation of staffing and economic policies as well as for the focused consolidation of personal interests and the economy as a whole;

$$
\text { proposed economic }
$$

models at different levels based upon spread lines of particular resources. Such models built upon balancing of some factors lacks scientific substantiation, according to their 
authors. Our method is based upon previous publications referenced herein. Generally, our conclusions would contribute to overcoming the crisis of economic science and formulation of a new reality- and objectivity-based paradigm.

\section{References}

Abalkin L.I., From Economic Theory of the Long-term Strategy Concept [Ot ekonomicheskoy teorii do kontseptsii budushchego strategiy] // Voprosy ekonomiki. M .: 2010. №6 s.4-10.

Afontsev S.A., The Policy of Institutional Change: from Theory to Practical Recommendations [Politika institutsionalnykh preobrazovaniy: ot teorii $\mathrm{k} \quad$ prakticheskim rekomendatsiyam] // Pod red. S.A. Afontseva. - M .: IMEMO RAN, 2013.s. 42.

Avtonomov V., Abstraction is the Mother of Order [Abstraktsiya - mat poryadka] // Voprosy ekonomiki. M.: NP «Voprosy ekonomiki» №4 2013g. s. 424.
Avtonomov V., Economic Theory in the

Institute of the World Economy and International

Relations [Ekonomicheskaya teoriya v IMEMO: sovetskiy period] // Voprosy ekonomiki M .: 2016. №11 s. 117-135.

Blaug M., cited by: M. Blaug, Economic Theory in Retrospect. Cambr.;N.Y. 1983. P.310.

Cherkovets V.N. et al., The World History of Economic Thought in 6 Volumes [Vsemirnaya istoriya ekonomicheskoy mysli v 6 tomakh] / V.N.Cherkovets, Ye.G.Vasilevskiy, V.A.Zhamin, I.P.Faminskiy i dr.M .: Izd-vo «Mysl'» 1987.Tom 1. - 606s.

Colander D. et al. Financial Crisis and the Failures of the Modern Economic Science [Finansovyy krizis i provaly sovremennoy ekonomicheskoy nauki] // Voprosy ekonomiki M .: 2010. №6 s. 1026.

Gilboa I., Postlethwaite E., Samuelson L., Schmeidler D., Economic Models as Analogies [Ekonomicheskiye modeli kak analogii] // Voprosy ekonomikiM .: 2015. №4 s. 106-130. 
Gilboa I., Postlethwaite E., Samuelson L., Schmeidler D., Economic Models as Analogies [Ekonomicheskiye modeli kak analogii] // Voprosy ekonomikiM .: 2015. №4 s. 106-130.

Kantorovich L.V., The Problems of Effective Use and Development of Transport [Problemy effektivnogo ispol'zovaniya i razvitiya transporta] [Internet-sayt $]=$ ru (data obrashcheniya 12.12.2017).

Kapitsa P.L., The Future of Science. Speech at the International Symposium on Science Planning on 20 September 1959 [Budushcheye nauki. Rech' na Mezhdunarodnom simpoziume po planirovaniyu nauki Praga, 20 sentyabrya 1959 g.] // «Mir nauki» 4, № 3-4, 2 (1960).

Keynes J.M., Introduction to the series: Cambridge Economics Handbooks [«Vvedeniye» k serii Spravochniki Kembridzhskoy ekonomiki] Tsitiruyetsya Sergiyenko L.V. Ekonomika [Elektronnyy resurs] URL: http: //nashaucheba.ru/v (data obrashcheniya 10.12.2017)
Keynes J.M., The General Theory of Employment, Interest and Money [Obshchaya teoriya zanyatosti, protsent $\mathrm{i}$ deneg] / M. Izd-vo «Gelios ARV» 2002g. s. 350.

Khasbulatov R.I., To a New Economic Model [K novoy ekonomicheskoy modeli] // Segodnya i zavtra Rossiyskoy ekonomiki. Nauchno-analiticheskiy sbornik .: M. Iz-vo «Ekonomicheskoye obozreniye» 2009g. s. 3-18.

Kumekhov K.K., Critics of the Classic Macroeconomic Modelling Theory [Kritika klassicheskikh teoriy makroekonomicheskogo modelirovaniya] // M .: Vestnik MGIMO Universiteta. 2015. №5 (44). S. 181-189. Kumekhov K.K., Kumekhova A.K., On the Problems and Ways of Development of the Modern Economic Theory [O problemakh i napravleniyakh dal'neyshego razvitiya sovremennoy ekonomicheskoy teorii] // Natsional'nyye interesy: prioritety i bezopasnost'. M. №20 (209) 2013.s.55. 
Kumekhov K.K., The Concept of Sectoral Structure in Modern Theory of Economy [Kontseptsiya otraslevoy struktury $\quad \mathrm{V}$ sovremennoy teorii ekonomiki] // Natsional'nyye interesy: prioritety i bezopasnost'. M. №43 (280) 2014.s.38-51

Kumekhov K.K., Theoretic Substantiation of Two-level Structure of the Macroeconomic Model [Teoreticheskoye obosnovaniye dvukhurovnevoy konstruktsii makroekonomicheskoy modeli] // Modeli, sistemy, seti $\mathrm{v}$ ekonomike, tekhnike, prirode i obshchestve. 2017. №2 (22) s. 69-87.

Lemeshchenko P.S., Problems of Development of Modern Economic Science [Problemy razvitiya sovremennoy ekonomicheskoy nauki] // M.1997. - № 3.s. 8.
List of Countries by GDP [Spisok stran po VVP 2017, v \$ mlrd.] [Elektronnyy resurs]

URL:

http://investorschool.ru/rejting-stran-povvp-2017.

Menshikov S.M., The Topicality of the Economic Model of L.V. Kantorovich Nowadays [Aktualnost ekonomicheskoy modeli L.V. Kantorovicha $\mathrm{v}$ nashe vremya] [Elektronnyy resurs] Rezhim dostupa:

http://www.fastcenter.ru/smenshikov/K antorovich.htm. (data obrashcheniya 22.06.2017).

Mil J.S. 1, The Principles of Political Economy with Some of Their Applications to Social Philosophy [Osnovy politicheskoy ekonomii s nekotorymi prilozheniyami k sotsial'noy filosofii] / Dzh.S.Mil': [per. s s ang., biograf. Ocherk Tugan-Baranovskogo M.I.] .- M.: Eksmo, 2007.s.989.

Nemchinov V.S., Economic Mathematical Methods and Models [Ekonomiko-matematicheskiye metody $\mathrm{i}$ modeli] / Nemchinov V.S. Izdatelstvo: "Gosudarstvennoye sotsialno- 
ekonomicheskoye izdatelstvo" 1962M. 412 s.

Nureyev R., Thorstein Veblen: a Look from the XXI Century [Torsteyn Veblen: vzglyad iz XXI veka] // Voprosy ekonomiki. 2007. № 7. C. 73-85.

Ozhegov S.I., Shvedova N.Yu., Explanatory Dictionary of the Russian Language [Tolkovyy slovar' russkogo yazyka] / Rossiyskaya akademiya nauk. Institut russkogo yazyka im. V.V.Vinogradova. - 4-ye izd., Dopolnennoye. - $\mathrm{M} \quad \therefore$ OOO Tekhnologii», 2006. S. 492.

Petrov A.A., Pospelov I.G., Mathematical Modelling of the Economy of Russia [Matematicheskiye modeli ekonomiki Rossii] / Vestnik Rossiyskoy akademii nauk. 2009. T. 79. Net 6. S. 492-506. [Elektronnyy resurs] Rezhim dostupa: http://www.ras.ru/FStorage/download.a spx?Id=d4f4d061-28d5-4c7c-8a65ef8e1e3ac11(data obrashcheniya 02.06.2017).

Plato. The State. Source: Plato. Collected works in 3 Volumes [Platon.
Gosudarstvo. Istochnik: Platon. Sobraniye sochineniy v 3-kh tt.] T.3 (1). — M., $1971 \mathrm{~g}$.

Polterovich V.M. (1990), Economic Equilibrium and Economic Mechanism [Ekonomicheskoye ravnovesiye i khozyaystvennyy mekhanizm] - M .: Nauka. S. 256.

Polterovich V.M., Crisis of Economic Theory [Krizis ekonomicheskoy teorii] [Elektronnyy resurs] URL: http: //www.nbrilev.ru/krizis_economic_theo ry_htm (data obrashcheniya 18.10.2016).

Porokhovsky A.A., Course of Economic Theory. Manual. $6^{\text {th }}$ Edition Corrected, Amended and Reworked [Kurs ekonomicheskoy teorii: uchebnik - 6-ye ispravlennoye, dopolnennoye i pererabotannoye izdaniye] - Kirov: «ASA», 2007g. s. 32.

Procedure of Formation and Structure of Governments of the Foreign Countries [Poryadok formirovaniya i struktura Interneta [] [Elektronnyy resurs] URL: http://www.studylaw.narod.ru/mishin/m 
ishin_10_2.htm (data obrashcheniya 18.012.2017).

Radygin A.D., Entov R.M., [«Провалы государства»: теория и политика] // М.: Вопросы экономики. 2012. №12. C. 4-30.

Resolution of the State Committee for Statistics of the RF of December 31, 1997 No. 99 on Approval of the Regulations on the Administration of National Accounts [Postanovleniye Goskomstata RF ot 31.12.1997 N $99 \mathrm{Ob}$ utverzhdenii Polozheniya ob Upravlenii natsional'nykh schetov] - [Elektronnyy resurs]

URL: http://www.bestpravo.ru/rossijskoje/ljzakony/o5b.htm

Ruzavin G.I., Fundamental and Applied Studies in Structure [Fundamentalnyye i prikladnyye issledovaniya $\mathrm{v}$ strukture] Tsentr gumanitarnykh tekhnologiy. Informatsionno-analiticheskiy portal [Elektronnyy resurs] URL: http: //gtmarket.ru/laboratory/expertize/6202 (data obrashcheniya 18.01.2016).

Samuelson P.A., Nordhaus W.D., Economics. Fifteenth Edition
[Ekonomika. Izdaniye pyatnadtsatoye] M. Iz-vo KnoRus 1997g. s.40.

Samuelson P.A., Nordhaus W.D., Economics. Fifteenth Edition [Ekonomika. Izdaniye pyatnadtsatoye] M. Iz-vo KnoRus 1997g. s.40.

Samuelson P.E., 1947. Printed in 1983. Fundamentals of Economic Analysis [Osnovy ekonomicheskogo analiza] Garvardskiy universitet.

Science [Nauka] - [Elektronnyy resurs] URL: http://ru.science.wikia.com/wiki/ (data obrashcheniya 18.10.2017).

Smith A., [Issledovaniye o prirode i prichinakh bogatstva narodov] [Elektronnyy resurs] URL: http://www.ek-lit.org/smit012.htm (data obrashcheniya 18.01.2018).

Stiglitz J., Failures of Corporate Management in Transition to the Market [Neudachi korporativnogo upravleniya pri perekhode $\mathrm{k}$ rynku] // Ekonomicheskaya nauka sovremennoy Rossii. № 4, 2001 g s. 108.

Sukharev O.S., Methodology and Abilities of the Economic Science 
[Metodologiya i vozmozhnosti

ekonomicheskoy nauki] - Monografiya. /

O.S.Sukharev- M $\quad \therefore \quad$ KURS: NITS

INFRA-M, 2013. S. 43.

Weber M. Wirtschaft und Gesellschaft.

Tubingen, 1976. S.133, 134.

Zhangissina G.D., Methodology of Development of Lecturing Materials for the Course of the Basics of Scientific Research [Metodika razrabotki lektsionnogo materiala po distsipline «Osnovy nauchnykh issledovaniy»] [Elektronnyy resurs] URL: http: //www.rusnauka.com/14_NPRT_2010/P edagogica/67171.doc.htm (data obrashcheniya 18.01.2016).

Zinovyev A.A., Ideology of the Party of the Future [Ideologiya partii budushchego] M .: Algoritm, 2003 g. [Elektronnyy resurs] URL: http://conflictmanagement.ru/nauchnyiy -podhod(data obrashcheniya 10.12.2015). 